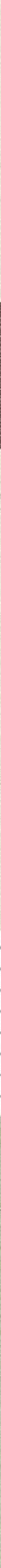




\title{
O índice de progresso social dos munícipios de Santa Catarina (2010-2017)
}

\author{
The Social Progress Index of \\ municipalities of Santa Catarina
}

\author{
Michele Romanello* \\ http://dx.doi.org/10.51861/ded.dmvu.1.013 \\ Recebido em 16 de setembro de 2020. Aceito em 10 de fevereiro de 2021.
}

\begin{abstract}
Resumo
O artigo segue a visão da avaliação de progresso social centrada nas capacitações das pessoas, medindo o bem-estar dos municípios do estado de Santa Catarina no período 2010-2017. A metodologia utilizada neste trabalho para construir um índice é uma adaptação da abordagem utilizada pelo Social Progress Index (SPI). A primeira conclusão é que parece que o progresso social tem uma relação mais evidente com o Índice de Desenvolvimento Humano (IDH) do que com o PIB per capita. A segunda conclusão do trabalho é que a maioria dos municípios, mesmo aqueles que ocupam as melhores posições em termos de desenvolvimento social, precisam melhorar pelo menos uma dimensão do progresso social.A terceira conclusão é que os municípios com menor índice estão, em geral, nas mesorregiões oeste, serrana e parte da mesorregião norte; por outro lado, os municípios com o melhor índice estão localizados no leste do estado de Santa Catarina.
\end{abstract}

Palavras-chave: Santa Catarina; capacitações; progresso social; bem-estar.

\begin{abstract}
This paper follows the vision of social progress evaluation focused on the capabilities of the people, measuring the wellbeing of the municipalities of the state of Santa Catarina in the period 2010-2017.The methodology used in this work to construct an index is an adaptation of the approach used by the Social Progress Index (SPI). The first conclusion is that it seems that social progress has a more evident relationship with the Human Development Index (HDI) than with GDP per capita. The second conclusion of the paper is that most municipalities, even those with the best positions in terms of social development, need to improve at least one dimension of social progress. The third conclusion is that the municipalities with the lowest index are, in general, the mesoregions west, mountain and part of the northern mesoregion; on the other hand, the municipalities with the best index are located in the eastern part of the state of Santa Catarina.
\end{abstract}

Keywords: Santa Catarina; capabilities; social progress; well-being.

\footnotetext{
* Doutor em Desenvolvimento Econômico. Departamento de Economia e Relações Internacionais Universidade Federal de Santa Catarina. Departamento de Economia e Relações Internacionais, Universidade Federal de Santa Catarina. R. Eng. Agronômico Andrei Cristian Ferreira, s/n. Trindade, Florianópolis. https://orcid.org/0000-0001-6295-8749. E-mail: romanello.michele@gmail.com
} 


\section{INTRODUÇÃO}

A abordagem de desenvolvimento e capacidade humana argumenta que a expansão da liberdade humana e, portanto, a redução de privações e pobreza multidimensional, é o objetivo essencial e o direcionador do desenvolvimento (SEN, 1982, 1988; UNDP, 2016). O bem-estar é avaliado do ponto de vista da habilidade de uma pessoa de realizar atos ou alcançar estados valiosos. Sen (1992) introduz o conceito de capacitação, definindo-o como a liberdade de um indivíduo ou grupo de alcançar várias combinações de funcionamentos (ser e fazer) em uma sociedade. Sen (1992) define a abordagem das capacitaçôes de forma completamente distinta das abordagens mais tradicionais de avaliação do bem-estar de uma sociedade. Essas abordagens eram baseadas em variáveis como renda real ou renda real per capita. A abordagem das capacitaçóes considera, em vez, os funcionamentos como elementos constituintes do bem-estar e a capacitação como liberdade para buscar esses elementos constitutivos. A renda, nas várias formas, pode ser incluída entre os meios para alcançar a liberdade, dependendo do indivíduo e da sociedade que estamos considerando. Para Sen (1992) as capacitaçôes são uma maneira de entender a liberdade como "liberdade positiva" do indivíduo, pois expressam a sua liberdade e possibilidade de alcançar o tipo de vida que prefere.

Uma extensa quantidade de pesquisas mostrou que o foco nas capacidades humanas e na liberdade, em vez do mero foco nas mercadorias ou no crescimento econômico, permite uma melhor compreensão de uma ampla gama de aspectos sociais e fenômenos como pobreza, desigualdade ou qualidade de vida (SEN, 1982; 1988; NUSSBAUM, 2000; PNUD, 2016).

Os índices que medem o bem-estar social se conformaram assim com o passar do tempo a essa nova maneira de perceber o desenvolvimento: enquanto a medição do bem-estar no começo do século passado era baseado em aspectos econômico, nos últimos 30 anos temos, em vez, o surgimento de muitos índices que seguem a abordagem das capacidades humanas.

A medição do bem-estar é uma atividade econômica e estatística que começou nos anos 30 do século anterior: o economista Simon Kuznets tinha como objetivo encontrar uma maneira de medir a economia dentro do esforço de encontrar saídas para a crise. Kuznets começou tentando medir o que era produtivo de maneira significativa, o que realmente trazia bemestar à sociedade e assim criou o Produto Interno Bruto (PIB). Até então, muitas estatísticas haviam sido criadas - elas mostravam quantos quilômetros de ferrovias existiam, a quantidade de ferro produzida etc. -, mas ninguém tentou unificá-las em uma única medida. Após a Segunda Guerra Mundial, esta iniciativa anglo-americana foi estendida pelas Nações Unidas e se tornou o padrão global para medir o bem-estar por muitas décadas (COYLE, 2014). 
Somente na década de 90, temos o surgimento de um novo método de medição de bem-estar, o Índice de Desenvolvimento Humano, que tem o objetivo de mudar o foco do desenvolvimento econômico da contabilidade nacional de renda para políticas centradas nas pessoas (HAQ, 1995). Mais recentemente, em 2010, a Iniciativa Pobreza e Desenvolvimento Humano de Oxford e o Programa das Naçóes Unidas para o Desenvolvimento criaram o Índice de Pobreza Multidimensional com o objetivo de capturar as severas privações que cada pessoa enfrenta ao mesmo tempo em relação à educação, saúde e padróes de vida (ALKIRE et al., 2011). Além disso, foram propostos vários indicadores baseados nas capacidades humanas, como o Índice de Desenvolvimento Humano (IDH), o Índice de Desenvolvimento Humano Ajustado pela Desigualdade (HDIAD) ou o Índice de Pobreza Multidimensional (MPI) (PNUD 2016; UL HAQ, 1973; ALKIRE \& FOSTER, 2011).

Este artigo segue essa visão da avaliação centrada nas capacitações das pessoas, medindo o bem-estar dos municípios do estado de Santa Catarina no período 2010-2017.

Santa Catarina é uma das 27 unidades federativas do Brasil, localizadas na região sul do país. É o 20 estado brasileiro por área territorial e o 11응 por população. Além disso, é a 9a maior população, com 295 municípios (Pontes, 2017). No campo empírico, medir o bem-estar nos municípios envolve dois problemas. Primeiro, um conjunto relevante de indicadores capazes de abordar todas as dimensóes da qualidade de vida deve ser identificado. Essas dimensões estão relacionadas ao desenvolvimento econômico, social, ambiental e urbano do município. Para avaliar as diferenças entre os municípios, devem ser coletados dados comparáveis e referentes a um período curto de tempo. Em segundo lugar, os indicadores devem ser agregados de forma sensata para construir um índice do bem-estar que permita classificar os municípios e relatar as possibilidades gerais de melhoria (GONZÁLEZ et al., 2011).

A metodologia utilizada neste trabalho para construir um índice é uma adaptação da abordagem utilizada pelo Social Progress Index (SPI). O SPI mede até que ponto os países atendem às necessidades sociais e ambientais de seus cidadãos. $\mathrm{O}$ índice combina três dimensões: Necessidades humanas básicas, Fundamentos do bem-estar e Oportunidade. Duas característicaschave do Índice de Progresso Social são a exclusão de variáveis econômicas e o uso de medidas de resultados, em vez de insumos, como cobertura de serviços realmente disponíveis, variação na incidência de doenças ou exposição à violência. (PULICI et al., 2017). 


\section{OBJETIVOS E CONTRIBUIÇÕES DO TRABALHO}

O objetivo principal do artigo é aplicação aos municípios do estado de Santa Catarina de uma nova metodologia para medir o bem-estar no mundo contemporâneo.

Nas últimas décadas o tema da medição do bem-estar teve uma crescente atenção por parte dos pesquisadores em ciências sociais e das organizaçóes internacionais. A qualidade dos índices de bem-estar e de desenvolvimento melhoraram constantemente desde a parte final do século anterior. A ONU quebrou o monopólio do PIB em 1990, com indicadores de desenvolvimento humano, medindo, além da renda, os níveis de acesso à saúde e à educação. Ao nível internacional, o índice Happy Planet no Reino Unido, os indicadores de qualidade de vida Calvert Henderson nos EUA e várias outras metodologias levaram em conta o fato de que aspectos da qualidade de vida, bem como os desafios sociais e ambientais, são fundamentais muito além dos resultados econômicos (ABDALLAH et al., 2009). A própria União Europeia lançou o programa Além do PIB, enquanto a Comissão Stiglitz-Sen-Fitoussi fez um excelente balanço do cenário das contas nacionais, deixando claras as limitações do PIB como instrumento de mensuração (Stiglitz, et al. 2018).

Hashimoto e Ishikawa (1993) propuseram o uso de Data Envelopment Analysis (DEA) para avaliar a qualidade de vida nas 47 prefeituras do Japão, e González et al. (2011), que mediram a qualidade de vida dos 237 maiores municípios espanhóis usando a Análise de Eficiência de Valor (VEA) para obter pontuaçóes comparativas, agregando as informaçóes contidas em 19 indicadores parciais.

Este artigo contribuirá a literatura brasileira sobre o assunto, calculando o Índice de Progresso Social para os municípios de Santa Catarina. O Social Progress Imperative criou o Índice de Progresso Social, que mede até que ponto os países atendem às necessidades sociais e ambientais de seus cidadãos. No Brasil, foram calculados dois índices ao nível local: Índice de Progresso Social da cidade do Rio de Janeiro, que traz uma análise por região administrativa da cidade e Índice de Progresso Social da Amazônia, com o objetivo de evidenciar desafios sociais e carência de oportunidades para a maioria da população amazônica (SANTOS et al., 2018).

Um trabalho com o mesmo objetivo de medir o bem-estar, mas com uma metodologia diferente, focada na pobreza multidimensional, foi desenvolvido por Moraes et al. (2018), as quais aplicaram o método de AlkireFoster (2009) para os municípios de Santa Catarina. A conclusão é que os municípios mais vulneráveis estão localizados, em geral, nas mesorregióes oeste, serrana e parte da mesorregião norte. Os municípios com os melhores 
percentuais estão localizados na parte leste do estado de Santa Catarina, ocupando quase todo o litoral do estado.

Ao analisar os resultados do índice, ulteriores objetivos do artigo são: conferir se o índice calculado tem uma relação com o IDH ou PIB per capita, verificar se os melhores municípios necessitam aperfeiçoar algumas dimensões do progresso social e analisar geograficamente o índice, localizando clusters de munícipios.

\section{SANTA CATARINA: UMA BREVE DESCRIÇÃO}

Santa Catarina, localizada na Região Sul do Brasil, possui uma população de 6.248.436 habitantes, segundo o Censo de 2010, distribuídos em 295 municípios em uma área de $95.733,98 \mathrm{~km}^{2}$ e com densidade populacional de 65,27 hab $/ \mathrm{km}^{2}$. Segundo o IBGE (2018), o estado pode ser dividido em seis mesorregiốes e vinte microrregióes. A Figura 1 a seguir mostra o estado de Santa Catarina com a divisão em mesorregióes estabelecida pelo IBGE.

Figura 1. Mesorregiões de Santa Catarina

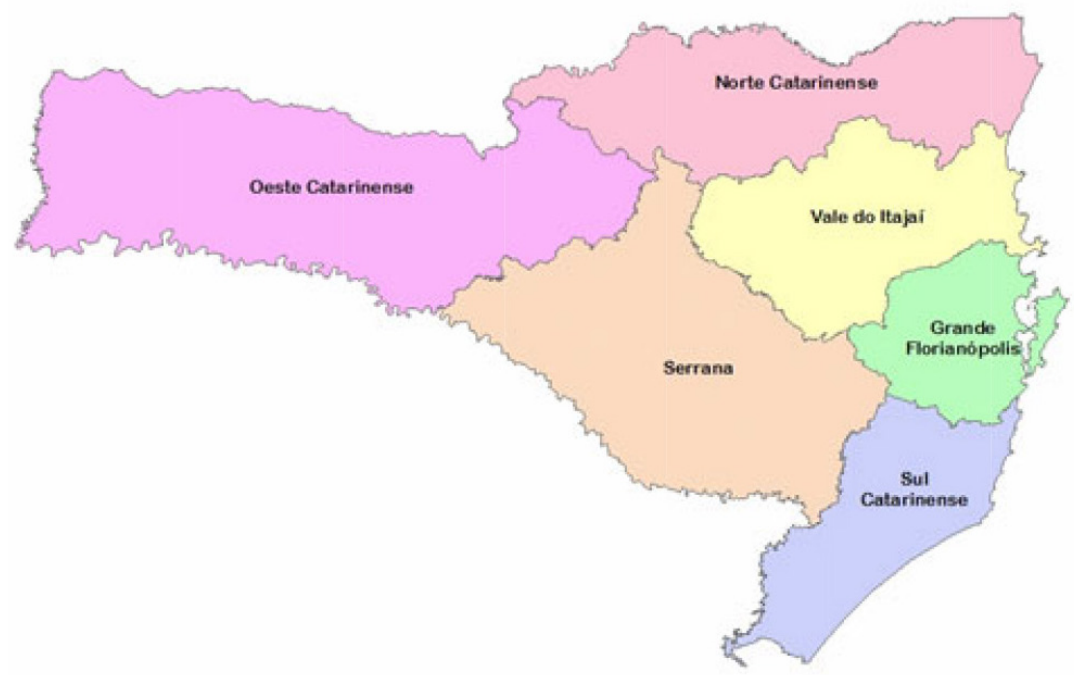

Fonte: elaboração própria com base nas Malhas Digitais fornecidas pelo IBGE, Censo 2010

Os índices sociais do estado estão entre os mais altos do país e da América do Sul. Possui o maior índice de expectativa de vida do país, menor taxa de mortalidade infantil e menor desigualdade econômica e analfabetismo no 
Brasil. Santa Catarina é considerada um estado rico e tem o sexto maior PIB do país, com uma economia variada (IBGE, 2018).

\section{METODOLOGIA PARA A CONSTRUÇÃO DO ÍNDICE DE PRO- GRESSO SOCIAL}

A metodologia para o calculo do índice que mede o progresso social envolve a construção de três dimensões compostas por quatro componentes cada, totalizando 12 componentes, conforme a Figura 2.

Figura 2. Dimensões e componentes do índice

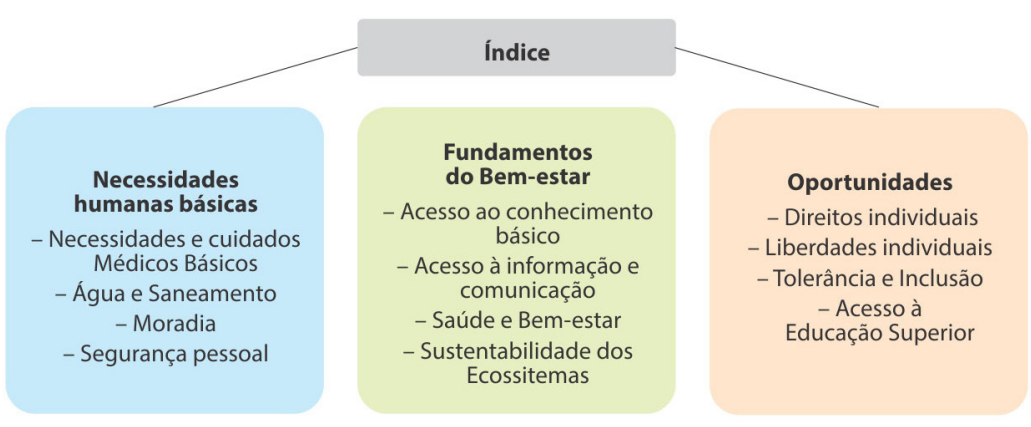

Fonte: Pulici et al. (2017)

A primeira dimensão, Necessidades Humanas Básicas, procura responder em que medida as necessidades essenciais da população são satisfeitas: nutrição, cuidados básicos de saúde, acesso a água potável e saneamento adequado, acesso a habitação decente e segurança pessoal.

A segunda dimensão, Fundamentos do bem-estar, procura responder em que medida as estruturas sociais garantem a manutenção de níveis de bem-estar e seu constante aprimoramento. A dimensão inclui o acesso à educação básica e sua qualidade, acesso às tecnologias de informação e comunicação, saúde e bem-estar mais amplo, considerando a mortalidade por doenças crônicas evitáveis e fatores de risco, bem como a sustentabilidade dos ecossistemas, como o uso sustentável recursos naturais e energéticos e preservação dos biomas.

A terceira dimensão, Oportunidade, tenta medir em que grau a sociedade oferece oportunidades para que todos possam realmente perseguir seus objetivos pessoais e alcançar seu potencial. A dimensão compreende os direitos individuais básicos, o direito de ir e vir e os direitos políticos essenciais, 
bem como a liberdade de escolha no nível individual, incluindo questôes como gravidez precoce e acesso a métodos contraceptivos, trabalho infantil e escravo e acesso a arte, cultura e lazer. A dimensão Oportunidade também abrange a questão da tolerância religiosa e das minorias, os direitos das mulheres e a inclusão social de grupos desfavorecidos, bem como o acesso ao ensino superior (PULICI et al., 2017).

As fontes utilizadas foram principalmente de dados administrativos estaduais e nacionais referentes ao período $2010-2017^{1}$ (Figura 3) ${ }^{2}$. A principal base de dados utilizada do Instituto Brasileiro de Geografia e Estatística foi o Censo 2010.

Figura 3. Fontes de dados.

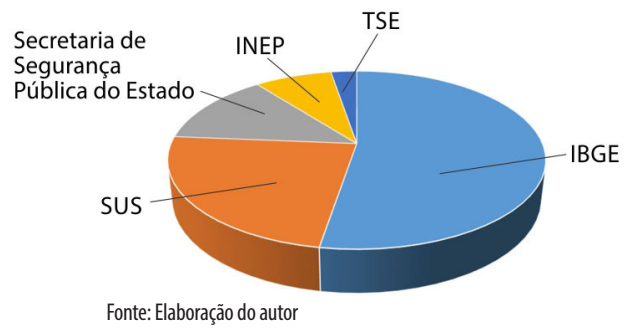

O cálculo do índice ocorre após várias etapas.

O primeiro passo é a padronização da série de dados: a média da série é subtraída de cada observação e a diferença dividida pelo desvio padrão, de modo que a nova série tenha média igual a zero e desvio padrão igual a um:

$$
z_{i}=\left(v_{i}-V_{\mu}\right) / V_{\sigma}
$$

onde $z_{i}$ é uma observação padronizada do valor de $v_{i}, V_{\mu}$ é a média e $V_{\sigma}$ o desvio padrão da série original, dando origem a um vetor $Z$ (z-scores) de observações padronizadas de $\mathrm{V}$.

O segundo passo é a análise de consistência interna entre indicadores padronizados dentro de cada componente. Os indicadores são selecionados em cada componente por meio da medida de covariância alfa de Cronbach, procurando coeficientes alfa acima de 0,7 , quando possível (ver Tabela 1). 
Tabela 1. Alpha de Cronbach e KMO

\begin{tabular}{l|c|c}
\hline Componente & $\begin{array}{c}\text { Alpha de } \\
\text { Cronbach }\end{array}$ & KMO \\
\hline Necessidades e cuidados Médicos Básicos & $\cdot$ & $\cdot$ \\
\hline Água e Saneamento & 0,73 & 0,69 \\
\hline Moradia & 0,66 & 0,59 \\
\hline Segurança Pessoal & 0,51 & 0,63 \\
\hline Acesso ao conhecimento Básico & 0,82 & 0,80 \\
\hline Acesso à Informação E comunicação & $\cdot$ &. \\
\hline Saúde e Bem-Estar & 0,46 & 0,63 \\
\hline Sustentabilidade dos Ecossistemas & 0,67 & 0,56 \\
\hline Direitos Individuais & 0,71 & 0,55 \\
\hline Liberdades Individuais & 0,63 & 0,57 \\
\hline Tolerância e Inclusão & $\cdot$ &. \\
\hline Acesso à Educação Superior & 0,74 & 0,58 \\
\hline
\end{tabular}

Fonte: elaboração própria

$\mathrm{Na}$ terceira etapa, é calculado um peso w para cada vetor (cada variável) pertencente a um determinado componente, por meio de análise fatorial das variáveis de cada componente, utilizando apenas a primeira carga fatorial atribuída a cada vetor.

$\mathrm{Na}$ quarta etapa, a robustez da análise fatorial é avaliada usando o teste Kaiser-Meyer-Olkin (KMO), com resultados acima de 0,5 (ver Tabela 1).

$\mathrm{Na}$ quinta etapa, cada peso representando a carga fatorial equivalente de cada uma das $n$ variáveis é normalizado para a unidade, somando todos os seus valores e dividindo cada valor pela soma de w (ver tabela A2 em anexos).

$\mathrm{Na}$ sexta etapa, a nota de cada observação em cada componente é calculada multiplicando $z_{\mathrm{i}}$ por $\mathrm{w}$ o peso atribuído a cada variável por meio da análise fatorial, de modo que a nota componente $\mathrm{C}$ seja dada por:

$$
C=\sum w_{i} z_{i}
$$

Finalmente, a nota de cada uma das dimensóes é calculada pela média simples das notas de cada um dos quatro componentes que a compóem. A nota do índice é a média simples do valor de cada uma das três dimensóes (Pulici, et al.2017).

\section{RESULTADOS}

A Tabela A3, em anexo, mostra os índices de todos os municípios de Santa Catarina. A seguir, os índices serão analisados de três formas: relação com o PIB per capita e IDH, dimensôes que componem os índices e a análise geografica. 


\section{RELAÇÃO DO ÍNDICE DE PROGRESSO SOCIAL (SPI) COM PIB PER CAPITA E IDH}

A Tabela 2 mostra os valores do índice dos primeiros 20 municípios calculados com a metodologia do Índice de Progresso Social ${ }^{3}$ e, por razóes de comparação, o Índice de Desenvolvimento Humano Municipal (IDHM). Pode-se notar que metade desses municípios está presente em ambas as partes da tabela, ou seja, algumas cidades estão em boa situação independentemente do índice utilizado para mensurar o desenvolvimento, e outras cidades são avaliadas positivamente de acordo com os aspectos considerados no cálculo de cada índice.

Tabela 2. Valores do índice (SPI) e do IDHM (2010) nos primeiros 20 municípios

\begin{tabular}{|c|c|c|c|c|c|}
\hline & Município & SPI & & Município & $\begin{array}{l}\text { IDHM } \\
(2010)\end{array}$ \\
\hline 1 & Arroio Trinta & 74,36 & 1 & Florianópolis & 0,847 \\
\hline 2 & Luzerna & 72,71 & 2 & Balneário Camboriú & 0,845 \\
\hline 3 & Jaraguá do Sul & 72,31 & 3 & Joaçaba & 0,827 \\
\hline 4 & lomerê & 70,88 & 4 & Joinville & 0,809 \\
\hline 5 & Timbó & 70,79 & 4 & São José & 0,809 \\
\hline 6 & Itapiranga & 70,15 & 6 & Blumenau & 0,806 \\
\hline 7 & Cocal do Sul & 69,87 & 6 & Rio Fortuna & 0,806 \\
\hline 8 & São João do Oeste & 69,58 & 8 & Jaraguá do Sul & 0,803 \\
\hline 9 & Florianópolis & 69,35 & 9 & Rio do Sul & 0,802 \\
\hline 10 & Joaçaba & 68,96 & 10 & São Miguel do Oeste & 0,801 \\
\hline 11 & São Ludgero & 68,96 & 11 & Concórdia & 0,800 \\
\hline 12 & Peritiba & 68,88 & 12 & Itapema & 0,796 \\
\hline 13 & Antônio Carlos & 68,59 & 12 & Tubarão & 0,796 \\
\hline 14 & Blumenau & 68,58 & 14 & Brusque & 0,795 \\
\hline 15 & Tubarão & 68,57 & 14 & lomerê & 0,795 \\
\hline 16 & Balneário Camboriú & 68,51 & 14 & Itajaí & 0,795 \\
\hline 17 & Pomerode & 68,20 & 14 & Treze Tílias & 0,795 \\
\hline 18 & Joinville & 68,17 & 18 & Chapecó & 0,790 \\
\hline 19 & Iporã do Oeste & 68,09 & 19 & Luzerna & 0,789 \\
\hline 20 & São Miguel do Oeste & 67,76 & 20 & Criciúma & 0,788 \\
\hline
\end{tabular}

Fonte: elaboração própria e PNUD (2010). Os municípios em negrito estão incluídos nos primeiros 20 municípios usando ambas as metodologias.

Uma situação comparável ocorre analisando os dados dos últimos 20 municípios, segundo o índice calculado com a metodologia do SPI e o Índice de Desenvolvimento Humano Municipal (IDHM) (Tabela 3). Nesse caso, também, metade dos municípios são os mesmos em ambas as partes da Tabela 3 . 
Tabela 3.Valores do índice (SPI) e do IDHM (2010) nos últimos 20 municípios

\begin{tabular}{l|l|c|c|l|c}
\cline { 2 - 6 } & \multicolumn{1}{c|}{ Município } & SPI & & \multicolumn{1}{c}{ Município } & $\begin{array}{c}\text { IDHM } \\
(\mathbf{2 0 1 0})\end{array}$ \\
\hline 274 & Dionísio Cerqueira & 52,99 & 274 & São Cristovão do Sul & 0,665 \\
\hline 275 & Monte Carlo & 52,88 & 275 & Painel & 0,664 \\
\hline 276 & Abelardo Luz & 52,84 & 276 & Macieira & 0,662 \\
\hline 277 & Campo Erê & 52,75 & 277 & Brunópolis & 0,661 \\
\hline 278 & Santa Cecília & 52,10 & 278 & Ipuaçu & 0,660 \\
\hline 279 & Matos Costa & 51,86 & 279 & Passos Maia & 0,659 \\
\hline 280 & Leoberto Leal & 51,66 & 280 & Timbó Grande & 0,659 \\
\hline 281 & Barra Bonita & 51,66 & 281 & Entre Rios & 0,657 \\
\hline 282 & Passos Maia & 51,63 & 282 & Matos Costa & 0,657 \\
\hline 283 & Cerro Negro & 51,03 & 283 & Capão Alto & 0,654 \\
\hline 284 & Paraíso & 50,95 & 284 & Saltinho & 0,654 \\
\hline 285 & São Cristovão do Sul & 50,72 & 285 & Rio Rufino & 0,653 \\
\hline 286 & Palmeira & 50,59 & 286 & Lebon Régis & 0,649 \\
\hline 287 & Guatambú & 49,84 & 287 & Bocaina do Sul & 0,647 \\
\hline 288 & Bandeirante & 49,63 & 288 & Monte Carlo & 0,643 \\
\hline 289 & Lebon Régis & 49,22 & 289 & Campo Belo do Sul & 0,641 \\
\hline 290 & Entre Rios & 48,04 & 290 & São José do Cerrito & 0,636 \\
\hline 291 & Timbó Grande & 47,80 & 291 & Vargem & 0,629 \\
\hline 292 & Ipuaçu & 42,82 & 292 & Calmon & 0,622 \\
\hline 293 & Calmon & 39,05 & 293 & Cerro Negro & 0,621 \\
\hline
\end{tabular}

Fonte: elaboração própria e PNUD (2010). Os municípios em negrito estão incluídos nos últimos 20 municípios usando ambas as metodologias.

A literatura evidencia que uma pré-condição do desenvolvimento econômico e da melhoria do bem-estar é o crescimento econômico. Segundo Ranis, et al. (2000), a ligação entre crescimento econômico e desenvolvimento humano pode ser descrita por uma relação de duas vias. A ligação envolve o crescimento econômico que beneficia o desenvolvimento humano por meio do PIB per capita. Com o aumento do PIB per capita, as famílias e os indivíduos aumentam os gastos, o que, por sua vez, leva ao crescimento do desenvolvimento humano. De fato, com o aumento das despesas, a arrecadação de impostos aumenta e, consequentemente, o investimento em saúde e educação cresce.

No entanto, algumas pesquisas sobre desenvolvimento sublinharam a necessidade de prestar muita atenção à conexão entre crescimento econômico e desenvolvimento humano, porque muitos países em desenvolvimento de rápido crescimento não alcançaram um bom nível de bem-estar de sua população. Em substância, altas taxas de crescimento do PIB per capita não conseguiram reduzir a privação socioeconômica de suas populações. Ao mesmo tempo, alguns países de baixa renda alcançaram altos níveis de desen- 
volvimento humano usando os poucos recursos disponíveis para desenvolver capacidades humanas básicas (STREETEN, 1994).

Assim, uma análise mais aprofundada que pode ser realizada é verificar se existe uma relação entre o nível de progresso social, medido pelo índice, e a renda per capita dos municípios de Santa Catarina. Esta análise é realizada através do seguinte gráfico (Figura 4), onde o eixo x representa o PIB per capita (2016) de cada município e o eixo y representa o índice calculado de acordo com a metodologia do Progresso Social.

Podemos observar que a correlação entre as duas variáveis é ligeiramente positiva: significa que a renda é importante para o progresso social, mas outras variáveis que explicam de maior grado o progresso social devem existir.

Figura 4. Correlação entre o Índice e o PIB per capita (2016)

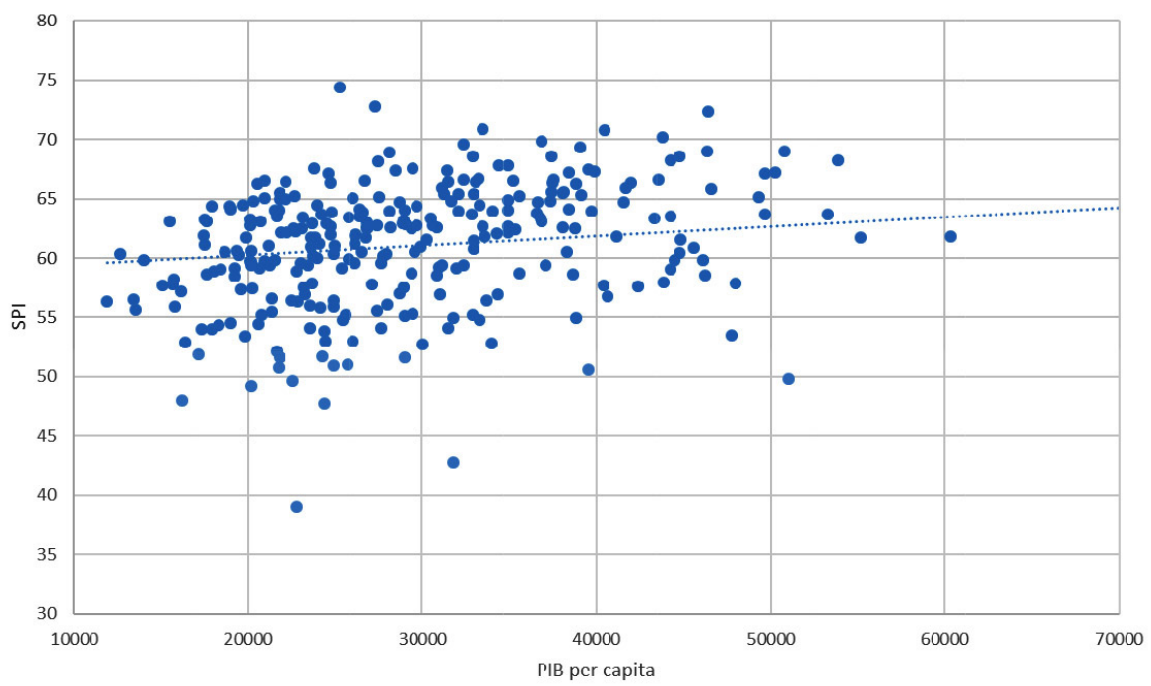

Fonte: elaboração própria.

\section{ANÁLISE DAS DIMENSÕES}

A tabela sucessiva (Tabela 4) mostra o valor das três dimensóes dos 20 primeiros municípios em cada dimensão.

Comparando esta tabela com a tabela 2, pode-se notar que apenas o município Arroio Trinta (o primeiro de acordo com a metodologia SPI) está presente nas três colunas da tabela 4, ou seja, Arroio Trinta é o único município que está incluído nos 20 melhores municípios de acordo com cada uma das dimensões: Necessidades Humanas Básicas, Fundamentos do Bem-Estar 
e Dimensões da Oportunidade. Os outros municípios que estão entre os 20 melhores segundo o índice geral do SPI estão incluídos na tabela 4 considerando apenas uma ou duas dimensões. Este fato indica que quase todos os municípios precisam melhorar alguma dimensão do progresso social.

Tabela 4. Valor das três dimensões dos primeiros 20 municípios

\begin{tabular}{|c|c|c|c|c|c|c|}
\hline & Município & $\begin{array}{c}\text { Necessidades } \\
\text { humanas } \\
\text { básicas }\end{array}$ & Município & $\begin{array}{l}\text { Fundamentos } \\
\text { do bem-estar }\end{array}$ & Município & Oportunidade \\
\hline 1 & $\begin{array}{l}\text { Jaraguá do } \\
\text { Sul }\end{array}$ & 86,95 & $\begin{array}{l}\text { São João do } \\
\text { Oeste }\end{array}$ & 75,48 & Luzerna & 70,02 \\
\hline 2 & $\begin{array}{l}\text { Balneário } \\
\text { Camboriú }\end{array}$ & 86,06 & $\begin{array}{l}\text { Arroio } \\
\text { Trinta }\end{array}$ & 74,07 & Lacerdópolis & 69,83 \\
\hline 3 & Timbó & 85,55 & $\begin{array}{l}\text { Iporã do } \\
\text { Oeste }\end{array}$ & 72,63 & $\begin{array}{l}\text { Alto Bela } \\
\text { Vista }\end{array}$ & 69,70 \\
\hline 4 & Rodeio & 84,84 & $\begin{array}{l}\text { Jaraguá do } \\
\text { Sul }\end{array}$ & 69,80 & $\begin{array}{l}\text { Santa Rosa } \\
\text { de Lima }\end{array}$ & 67,03 \\
\hline 5 & $\begin{array}{l}\text { São Bento } \\
\text { do Sul }\end{array}$ & 84,78 & Tunápolis & 69,62 & lomerê & 66,88 \\
\hline 6 & Arroio Trinta & 84,78 & Itapiranga & 69,42 & $\begin{array}{l}\text { Treze de } \\
\text { Maio }\end{array}$ & 66,06 \\
\hline 7 & São Ludgero & 84,59 & Treze Tílias & 68,36 & Florianópolis & 65,97 \\
\hline 8 & Botuverá & 84,58 & $\begin{array}{l}\text { São } \\
\text { Martinho }\end{array}$ & 68,20 & Tunápolis & 65,56 \\
\hline 9 & Blumenau & 84,33 & $\begin{array}{l}\text { Cocal do } \\
\text { Sul }\end{array}$ & 68,01 & Joaçaba & 64,24 \\
\hline 10 & Peritiba & 84,01 & Luzerna & 67,78 & Arroio Trinta & 64,24 \\
\hline 11 & Criciúma & 83,39 & $\begin{array}{l}\text { São } \\
\text { Ludgero }\end{array}$ & 67,26 & $\begin{array}{l}\text { Balneário } \\
\text { Camboriú }\end{array}$ & 64,09 \\
\hline 12 & Ibirama & 83,18 & $\begin{array}{l}\text { São Miguel } \\
\text { do Oeste }\end{array}$ & 67,20 & Frei Rogério & 64,03 \\
\hline 13 & Rio do Sul & 82,95 & Tijucas & 66,73 & São Martinho & 63,94 \\
\hline 14 & Brusque & 82,95 & $\begin{array}{l}\text { Antônio } \\
\text { Carlos }\end{array}$ & 66,69 & Peritiba & 63,56 \\
\hline 15 & Cocal do Sul & 82,72 & Atalanta & 66,15 & Salto Veloso & 63,30 \\
\hline 16 & Pomerode & 82,72 & Timbó & 65,28 & Ouro Verde & 63,14 \\
\hline 17 & Schroeder & 82,66 & Pomerode & 65,14 & São Bonifácio & 63,05 \\
\hline 18 & Tubarão & 82,52 & Joinville & 64,59 & Marema & 63,04 \\
\hline 19 & Itapema & 82,14 & $\begin{array}{l}\text { Pinheiro } \\
\text { Preto }\end{array}$ & 64,55 & Saudades & 63,01 \\
\hline 20 & Urussanga & 82,13 & Blumenau & 64,13 & Nova Veneza & 62,96 \\
\hline
\end{tabular}

Fonte: elaboração própria. 


\section{ANÁLISE DOS CLUSTERS GEOGRÁFICOS}

A Figura 5 mostra um mapa representando os resultados: cada município tem uma cor de acordo com o valor do índice. Quanto mais a cor está escura significa que o índice é alto, quanto mais clara significa que o índice é baixo.

Figura 5. Mapa dos munícipios de Santa Catarina de acordo com o SPI

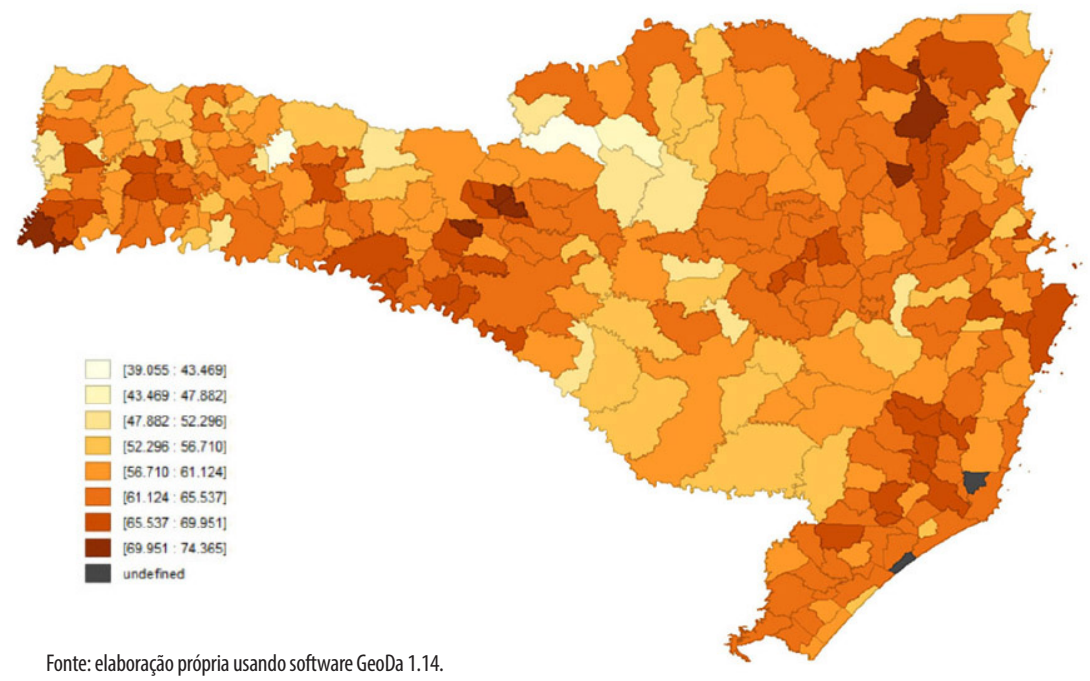

De acordo com a Figura 5 e a Tabela 5, a seguir, podemos ver que os municípios com alto índice de progresso social estão mais concentrados em algumas mesorregióes que em outras. Os municípios com menor índice são, em geral, nas mesorregióes oeste, serrana e parte da mesorregião norte. Por outro lado, os municípios com o melhor índice estão localizados na parte leste do estado de Santa Catarina, ocupando praticamente todo o litoral do estado, como é possível observar no mapa, o que inclui as mesorregióes da grande Florianópolis, o Vale do Itajaí e a mesorregião sul. Esse resultado está de acordo com o trabalho de Moraes et al. (2018).

Tabela 5. Valor médio do índice em cada região

\begin{tabular}{l|c}
\hline Mesorregião & Índice médio \\
\hline Grande Florianópolis & 61,37 \\
\hline Norte & 60,19 \\
\hline Oeste & 60,53 \\
\hline Serrana & 57,55 \\
\hline Sul & 63,34 \\
\hline Vale do Itajaí & 63,02 \\
\hline Fonte: elaboração própria.
\end{tabular}


Enfim, é interessante incluir a identificação de clusters por meio da estatística Moran local como última análise.

A estatística Moran local foi sugerida em Anselin (1995) como uma maneira de identificar clusters locais e outliers espaciais locais. A maioria das estatísticas de autocorrelação espacial global pode ser expressa como uma soma dupla sobre os índices i e j, como $\sum_{\mathrm{i}} \sum_{\mathrm{i}} \mathrm{g}_{\mathrm{ij}}$. A forma local dessa estatística seria, para cada observação (localização) i, a soma da expressão relevante sobre o índice $\mathrm{j}, \sum_{\mathrm{j}} \mathrm{g}_{\mathrm{ij}}$.

O mapa de cluster mostra os municípios significativos com uma indicação do tipo de associação espacial, com base na localização do valor e sua defasagem espacial no gráfico de dispersão de Moran. Utilizando os dados do SPI, todas as quatro categorias são representadas, com vermelho escuro para os clusters alto-alto, azul escuro para os clusters baixo-baixo, azul claro para os outliers espaciais baixo-alto e vermelho claro para os outliers espaciais alto-baixo.

De acordo com o mapa da Figura 6, 30 municípios são classificados como clusters alto-alto, a maioria na mesorregião do Vale do Itajaí; 26 municípios são classificados como clusters baixo-baixo, a maioria na mesorregião serrana; 8 municípios são classificados como outliers espaciais baixo-alto; 9 municípios são classificados como outliers espaciais alto-baixo.

Figura 6. Mapa de Santa Catarina de acordo com a análise de clusters.

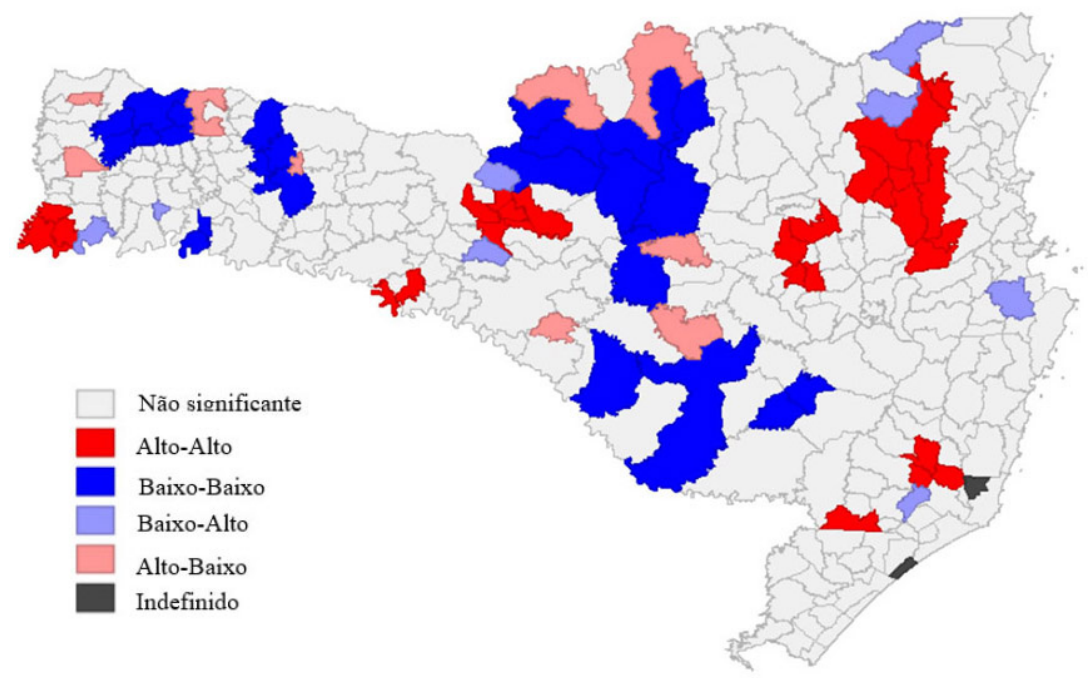

Fonte: elaboração própria usando software GeoDa 1.14 


\section{CONCLUSÕES}

A busca por indicadores, como instrumentos úteis de pesquisa, está avançando no Brasil e no resto do mundo. Considerando que o mundo está mudando e novos problemas estão surgindo, as sociedades precisam de uma população informada sobre novos desafios. Em primeiro lugar, o desafio ambiental, que está diretamente ligado à qualidade de vida da população. Em segundo lugar, o desafio social: em todo o mundo, há pessoas sem acesso aos "benefícios” da globalização. Em terceiro lugar, o desafio da governança: uma ferramenta indispensável para a alocação racional e a priorização do uso de recursos.

Nesse contexto, um índice de qualidade de vida abrangente, que reflita o desenvolvimento socioeconômico, é muito importante, porque permite aos formuladores de políticas de conhecer as condiçóes de vida da população de cada município e pode ser usado como referência para a elaboração de políticas públicas inclusivas.

Este artigo apresenta uma nova metodologia para medir o bem-estar considerando os novos desafios que as sociedades enfrentam.

Aplicando esta metodologia ao estado brasileiro de Santa Catarina, foi possível medir o nível de bem-estar e progresso social dos municípios do estado. Temos três principais conclusôes deste estudo.

A primeira conclusão é que parece que o progresso social tem uma relação mais evidente com o Índice de Desenvolvimento Humano (IDH) do que com o PIB per capita. Esse resultado implica que os munícipios podem melhorar o bem-estar dos próprios cidadãos utilizando outros meios além do crescimento da renda.

A segunda conclusão é que a maioria dos municípios, mesmo aqueles que ocupam as melhores posiçôes em termos de desenvolvimento social, precisam melhorar pelo menos uma dimensão do progresso social.

A terceira conclusão é que os municípios com menor índice estão, em geral, nas mesorregióes oeste, serrana e parte da mesorregião norte; por outro lado, os municípios com o melhor índice estão localizados no leste do estado de Santa Catarina, ocupando praticamente todo o litoral do estado. A análise geográfica identificou principalmente que existe um cluster de SPI elevado na mesorregião do Vale do Itajaí e um cluster de SPI baixo na mesorregião serrana.

\footnotetext{
Notas

' Não foi possível encontrar dados referentes a um único ano. Para cada variável foram utilizados os dados mais recentes.

${ }^{2}$ A tabela A1 em anexo mostra a explicação de cada variável utilizada no cálculo do índice.

${ }^{3}$ Os municípios de Balneário Rincão e Pescaria Brava foram retirados da análise do artigo, sendo munícipios de recente criação e, consequentemente, com pouco dados disponíveis.
} 


\section{Referências}

ABDALLAH, S.; THOMPSON, S.; MICHAELSON, J.; MARKS, N. \& STEUER, N. The Happy Planet Index 2.0: Why good lives don't have to cost the Earth. London: Nef (The New Economics Foundation), 2009.

ALKIRE, S. \& FOSTER, J. Counting and multidimensional poverty. In: BRAUN, J. et al. The poorest and hungry: assessment, analyses, and actions. Washington: International Food Policy Research Institute, 2009.

ALKIRE, S., ROCHE, J.M., SANTOS, M. E. \& $\mathrm{SETH}$, S. Multidimensional Poverty Index 2011: Brief Methodological Note. Oxford Poverty \& Human Development Initiative (OPHI), 2011.

ANSELIN, L. Local Indicators of Spatial Association - LISA. Geographical Analysis n. 27, pp. 93-115, 1995.

BRAZILIAN INSTITUTE OF GEOGRAPHY AND STATISTICS (IBGE) Cidades, 2018.

COYLE, D. GDP: A Brief but Affectionate History. Princeton: Princeton University Press, 2014.

GONZÁLEZ, E., CÁRCABA, A. VENTURA, J. \& GARCIA, J. Measuring quality of life in Spanish municipalities. Local Government Studies. v. 37, n. 2, 2011.

HAQ, M. Reflections on Human Development. New York: Oxford University Press, 1995.

HASHIMOTO, A. \& ISHIKAWA, H. Using DEA to evaluate the state of society as measured by multiple social indicators. Socio Economic Planning Sciences, n.27, pp. 257268, 1993.

MORAES, M. M., MARIN, S. R. \& VIEIRA, C.A. Pobreza multidimensional em Santa Catarina (2000-2010): Uma aplicação do método Alkire-Foster. Economia e Desenvolvimento, v. 7, n. 30, nov. 2018.
NUSSBAUM, M. C. Women and human development: The capabilities approach. New York: Cambridge University Press, 2000.

PONTES, H. M. M. IBGE - Agência de Notícias. IBGE - Agência de Notícias, 2017.

PULICI, A., CARVALHO MOURA, D. \& MOSANER, M. Índice de Progresso Social no Rio de Janeiro 2016. Social Progress Imperative, 2017.

RANIS, G. \& STEWARD, F. Dynamic Links between economic growths and Human Development. DESA Working Paper, n.8, 2005.

SANTOS, D., MOSANER, M., CELENTANO, D., MOURA R. \& VERÍSSIMO, A. Índice de Progresso Social na Amazônia brasileira: IPS Amazônia 2018. Belém, PA: Imazon; Social Progress Imperative, 2018.

SEN, A. K. Choice, welfare, and measurement. Oxford: Basil Blackwell, 1982.

SEN, A. Desigualdade reexaminada. Rio de Janeiro: Record, 1992.

STIGLITZ, J. E., FITOUSSI, J.P., \& DURAND, M. Beyond GDP: Measuring What Counts for Economic and Social Performance. Paris: OECD Publishing, 2018.

STREETEN,P.Human Development: Means and Ends. Human Development. v.84, n.2, p.232-237, 1994.

UNDP. Human Development Report 2016. Technical notes, 2016. 


\section{ANEXOS}

Tabela A1. Variáveis em cada componente e suas descrições

\begin{tabular}{|c|c|c|}
\hline Componente & Variáveis & Descrição \\
\hline \multirow[t]{2}{*}{$\begin{array}{l}\text { Necessidades e } \\
\text { cuidados médicos } \\
\text { básicos }\end{array}$} & Mortalidade materna & $\begin{array}{l}\text { Óbitos de mulheres que ocorrem até } 42 \text { dias } \\
\text { após o término da gestação, atribuídos a causas } \\
\text { relacionadas à gravidez, parto e puerpério, em } \\
\text { relação ao total de nascidos vivos. }\end{array}$ \\
\hline & Baixo peso ao nascer & $\begin{array}{l}\text { Proporção de nascidos vivos com peso inferior a } \\
2,500 \text { kg no momento da primeira pesagem. }\end{array}$ \\
\hline \multirow[t]{4}{*}{ Água e saneamento } & $\begin{array}{l}\text { Abastecimento de agua no } \\
\text { domicílio }\end{array}$ & $\begin{array}{l}\text { Proporção de domicílios cuja forma de } \\
\text { abastecimento de água é a rede geral de } \\
\text { distribuição. }\end{array}$ \\
\hline & $\begin{array}{l}\text { Rede de esgoto no } \\
\text { domicílio }\end{array}$ & $\begin{array}{l}\text { Proporção de residências cujo esgoto sanitário } \\
\text { ou sanitário é despejado na rede geral de } \\
\text { esgotos. }\end{array}$ \\
\hline & Domicílios com banheiro & $\begin{array}{l}\text { Proporção de domicílios com pelo menos um } \\
\text { banheiro. }\end{array}$ \\
\hline & Lixo coletado & $\begin{array}{l}\text { Proporção de lixo doméstico coletado } \\
\text { diretamente pelo serviço de limpeza. }\end{array}$ \\
\hline \multirow[t]{4}{*}{ Moradia } & Acesso à energia elétrica & $\begin{array}{l}\text { Proporção de residências que recebem } \\
\text { eletricidade de uma empresa de distribuição. }\end{array}$ \\
\hline & $\begin{array}{l}\text { Adensamento Habitacional } \\
\text { Excessivo }\end{array}$ & $\begin{array}{l}\text { Proporção de domicílios com mais de três } \\
\text { moradores por cômodo. }\end{array}$ \\
\hline & Máquina de lavar & $\begin{array}{l}\text { Proporção de domicílios com máquina de lavar } \\
\text { roupa. }\end{array}$ \\
\hline & Geladeira & Proporção de domicílios com geladeira. \\
\hline \multirow[t]{4}{*}{ Segurança pessoal } & Taxa de homicídio & $\begin{array}{l}\text { Número de mortes por homicídio e lesões } \\
\text { corporais seguidas de morte por } 100.000 \\
\text { habitantes. }\end{array}$ \\
\hline & Taxa de roubo de rua & $\begin{array}{l}\text { Taxas de ocorrência de roubo de rua por } 1.000 \\
\text { habitantes. }\end{array}$ \\
\hline & Taxa de latrocínio & $\begin{array}{l}\text { Taxas de ocorrência de roubo seguidas de } \\
\text { morte por } 1.000 \text { habitantes. }\end{array}$ \\
\hline & $\begin{array}{l}\text { Taxa de lesão corporal } \\
\text { dolosa }\end{array}$ & $\begin{array}{l}\text { Taxas de ocorrência de lesão corporal dolosa } \\
\text { por } 1.000 \text { habitantes. }\end{array}$ \\
\hline \multirow[t]{4}{*}{$\begin{array}{l}\text { Acesso ao } \\
\text { conhecimento básico }\end{array}$} & Alfabetização & $\begin{array}{l}\text { Proporção de crianças alfabetizadas até o } \\
\text { terceiro ano do ensino fundamental de escolas } \\
\text { públicas. }\end{array}$ \\
\hline & $\begin{array}{l}\text { Nota média IDEB - Anos } \\
\text { iniciais }\end{array}$ & $\begin{array}{l}\text { Nota média no Índice de Desenvolvimento da } \\
\text { Educação Básica (IDEB) para os anos iniciais. }\end{array}$ \\
\hline & $\begin{array}{l}\text { Nota média IDEB - Anos } \\
\text { finais }\end{array}$ & $\begin{array}{l}\text { Nota média no Índice de Desenvolvimento da } \\
\text { Educação Básica (IDEB) para os anos finais. }\end{array}$ \\
\hline & Distorção idade-série & $\begin{array}{l}\text { Proporção de alunos com mais de } 2 \text { anos de } \\
\text { atraso escolar. }\end{array}$ \\
\hline \multirow[t]{2}{*}{$\begin{array}{l}\text { Acesso à Informação e } \\
\text { comunicação }\end{array}$} & Telefone & $\begin{array}{l}\text { Proporção de domicílios com telefone celular ou } \\
\text { telefone fixo. }\end{array}$ \\
\hline & Internet & Proporção de domicílios com acesso à internet. \\
\hline \multirow[t]{4}{*}{ Saúde e Bem-Estar } & Focos de dengue & $\begin{array}{l}\text { Taxa de incidência de dengue por } 100.000 \\
\text { habitantes. }\end{array}$ \\
\hline & Casos de hanseníase & $\begin{array}{l}\text { Taxa de incidência de hanseníase por } 100.000 \\
\text { habitantes. }\end{array}$ \\
\hline & Casos de sífilis em gestante & $\begin{array}{l}\text { Taxa de incidência de sífilis em gestantes por } \\
100.000 \text { habitantes. }\end{array}$ \\
\hline & Casos de hepatite viral & $\begin{array}{l}\text { Taxa de incidência de hepatite viral por } 100.000 \\
\text { habitantes. }\end{array}$ \\
\hline
\end{tabular}


Tabela A1(cont.). Variáveis em cada componente e suas descrições

\begin{tabular}{|c|c|c|}
\hline Componente & Variáveis & Descrição \\
\hline \multirow[t]{3}{*}{$\begin{array}{l}\text { Sustentabilidade dos } \\
\text { Ecossistemas }\end{array}$} & $\begin{array}{l}\text { Taxa de recuperação } \\
\text { materiais recicláveis }\end{array}$ & $\begin{array}{l}\text { Taxa de recuperação de materiais recicláveis em } \\
\text { relação ao total coletado. }\end{array}$ \\
\hline & $\begin{array}{l}\text { Massa per capita de } \\
\text { materiais recicláveis } \\
\text { recolhidos }\end{array}$ & $\begin{array}{l}\text { Massa per capita de materiais recicláveis } \\
\text { coletados através de coleta seletiva. }\end{array}$ \\
\hline & Arborização & $\begin{array}{l}\text { Porcentagem de domicílio que estão localizados } \\
\text { em uma rua arborizada. }\end{array}$ \\
\hline \multirow[t]{3}{*}{ Direitos Individuais } & $\begin{array}{l}\text { Taxa de homicídios por } \\
\text { intervenção policial }\end{array}$ & $\begin{array}{l}\text { Taxa de homicídio por intervenção policial por } \\
100.000 \text { habitantes. }\end{array}$ \\
\hline & $\begin{array}{l}\text { Tempo deslocamento casa } \\
\text { - trabalho }\end{array}$ & $\begin{array}{l}\text { Tempo médio, em minutos, gasto no } \\
\text { deslocamento entre residência e atividade } \\
\text { principal. }\end{array}$ \\
\hline & Eleitores faltosos & $\begin{array}{l}\text { Proporção de eleitores ausentes sobre o total } \\
\text { de eleitores. }\end{array}$ \\
\hline \multirow[t]{3}{*}{ Liberdades Individuais } & Gravidez na Adolescência & $\begin{array}{l}\text { Proporção de nascidos vivos de mães até } \\
19 \text { anos. }\end{array}$ \\
\hline & Trabalho infantil & $\begin{array}{l}\text { Crianças ou adolescentes que realizam } \\
\text { atividades de trabalho por } 100.000 \text { habitantes. }\end{array}$ \\
\hline & $\begin{array}{l}\text { Bibliotecas, museus, teatros } \\
\text { e centros culturais }\end{array}$ & $\begin{array}{l}\text { Número de bibliotecas, museus, teatros e } \\
\text { centros culturais por } 100.000 \text { habitantes. }\end{array}$ \\
\hline \multirow[t]{2}{*}{ Tolerância e Inclusão } & $\begin{array}{l}\text { Taxa de violência contra } \\
\text { mulher }\end{array}$ & $\begin{array}{l}\text { Taxas de violência física e sexual contra } \\
\text { mulheres por } 100.000 \text { habitantes. }\end{array}$ \\
\hline & Vulnerabilidade Familiar & $\begin{array}{l}\text { Proporção de domicílios com mulher com } \\
\text { ensino fundamental incompleto como } \\
\text { responsável e filho(s) menor(es) de } 10 \text { anos ou } \\
\text { economicamente inativo(s). }\end{array}$ \\
\hline \multirow[t]{3}{*}{$\begin{array}{l}\text { Acesso à Educação } \\
\text { Superior }\end{array}$} & $\begin{array}{l}\text { Pessoas com ensino } \\
\text { superior }\end{array}$ & $\begin{array}{l}\text { Proporção da população de } 25 \text { anos ou mais } \\
\text { que completou Ensino Superior. }\end{array}$ \\
\hline & $\begin{array}{l}\text { Pessoas pretas, pardas } \\
\text { ou indígenas com ensino } \\
\text { superior }\end{array}$ & $\begin{array}{l}\text { Proporção da população que se autoidentifica } \\
\text { como preta, parda ou indígena com idade igual } \\
\text { ou superior a } 25 \text { anos que completou o Ensino } \\
\text { Superior. }\end{array}$ \\
\hline & $\begin{array}{l}\text { Frequência ao ensino } \\
\text { superior }\end{array}$ & $\begin{array}{l}\text { Proporção da população com idade entre } 18 \\
\text { e } 24 \text { anos que frequenta ou concluiu o Ensino } \\
\text { Superior. }\end{array}$ \\
\hline
\end{tabular}

Fonte: elaboração própria. 
Tabela A2. Carga fatorial e peso de cada variável

\begin{tabular}{|c|c|c|c|}
\hline Componente & Variável & $\begin{array}{l}\text { Carga } \\
\text { fatorial }\end{array}$ & Pesos \\
\hline \multirow{2}{*}{$\begin{array}{l}\text { Necessidades e cuidados } \\
\text { Médicos Básicos }\end{array}$} & Mortalidade materna & 0,31 & 0,50 \\
\hline & Baixo peso ao nascer & 0,31 & 0,50 \\
\hline \multirow[t]{4}{*}{ Água e Saneamento } & Abastecimento de agua no domicílio & 0,69 & 0,27 \\
\hline & Rede de esgoto no domicílio & 0,58 & 0,23 \\
\hline & Domicílios com banheiro & 0,47 & 0,19 \\
\hline & Lixo coletado & 0,78 & 0,31 \\
\hline \multirow[t]{4}{*}{ Moradia } & Acesso à Energia Elétrica & 0,52 & 0,22 \\
\hline & Adensamento Habitacional Excessivo & 0,64 & 0,27 \\
\hline & Máquina de lavar & 0,58 & 0,25 \\
\hline & Geladeira & 0,59 & 0,25 \\
\hline \multirow[t]{4}{*}{ Segurança Pessoal } & Taxa de homicídio & 0,60 & 0,23 \\
\hline & Taxa de roubo de rua & 0,63 & 0,25 \\
\hline & Taxa de latrocínio & 0,64 & 0,25 \\
\hline & Taxa de lesão corporal dolosa & 0,69 & 0,27 \\
\hline \multirow{4}{*}{$\begin{array}{l}\text { Acesso ao conhecimento } \\
\text { Básico }\end{array}$} & Alfabetização & 0,79 & 0,24 \\
\hline & Nota média IDEB - Anos iniciais & 0,76 & 0,24 \\
\hline & Nota média IDEB - Anos finais & 0,82 & 0,25 \\
\hline & Distorção idade-série & 0,86 & 0,27 \\
\hline \multirow{2}{*}{$\begin{array}{l}\text { Acesso à Informação e } \\
\text { comunicação }\end{array}$} & Telefone & 0,73 & 0,50 \\
\hline & Internet & 0,73 & 0,50 \\
\hline \multirow[t]{4}{*}{ Saúde e Bem-Estar } & Focos de dengue & 0,62 & 0,24 \\
\hline & Casos de hanseníase & 0,63 & 0,25 \\
\hline & Casos de síflis em gestante & 0,67 & 0,26 \\
\hline & Casos de hepatite viral & 0,63 & 0,25 \\
\hline \multirow{3}{*}{$\begin{array}{l}\text { Sustentabilidade dos } \\
\text { Ecossistemas }\end{array}$} & Taxa de recuperação materiais recicláveis & 0,62 & 0,33 \\
\hline & $\begin{array}{l}\text { Massa per capita de materiais recicláveis } \\
\text { recolhidos }\end{array}$ & 0,68 & 0,37 \\
\hline & Arborização & 0,56 & 0,30 \\
\hline \multirow[t]{3}{*}{ Direitos Individuais } & Taxa de homicídios por intervenção policial & 0,30 & 0,21 \\
\hline & Tempo deslocamento casa - trabalho & 0,56 & 0,38 \\
\hline & Eleitores faltosos & 0,60 & 0,41 \\
\hline \multirow[t]{3}{*}{ Liberdades Individuais } & Gravidez na Adolescência & 0,34 & 0,25 \\
\hline & Trabalho infantil & 0,49 & 0,36 \\
\hline & Bibliotecas, museus, teatros e centros culturais & 0,52 & 0,39 \\
\hline \multirow[t]{2}{*}{ Tolerância e Inclusão } & Taxa de violência contra mulher & 0,37 & 0,50 \\
\hline & Vulnerabilidade Familiar & 0,37 & 0,50 \\
\hline \multirow[t]{3}{*}{ Acesso à Educação Superior } & Pessoas com ensino superior & 0,81 & 0,40 \\
\hline & $\begin{array}{l}\text { Pessoas pretas, pardas ou indígenas com ensino } \\
\text { superior }\end{array}$ & 0,67 & 0,33 \\
\hline & Frequência ao ensino superior & 0,56 & 0,27 \\
\hline
\end{tabular}

Fonte: elaboração própria 
Tabela A3. SPI dos munícipios de Santa Catarina

\begin{tabular}{|c|c|c|c|c|c|c|c|c|c|}
\hline Município & SPI & Município & SPI & Município & SPI & Município & SPI & Município & SPI \\
\hline $\begin{array}{l}\text { Abdon } \\
\text { Batista }\end{array}$ & 61,96 & Capão Alto & 54,93 & Ipuaçu & 42,82 & Ouro & 64,77 & $\begin{array}{c}\text { São } \\
\text { Bernardino }\end{array}$ & 56,00 \\
\hline $\begin{array}{c}\text { Abelardo } \\
\text { Luz }\end{array}$ & 52,84 & Capinzal & 66,48 & Ipumirim & 61,79 & Ouro Verde & 62,49 & $\begin{array}{c}\text { São } \\
\text { Bonifácio }\end{array}$ & 64,39 \\
\hline Agrolândia & 63,54 & $\begin{array}{c}\text { Capivari de } \\
\text { Baixo }\end{array}$ & 63,84 & Iraceminha & 57,85 & Paial & 56,39 & São Carlos & 63,53 \\
\hline Agronômica & 63,46 & Catanduvas & 60,48 & Irani & 58,43 & Painel & 53,82 & $\begin{array}{c}\text { São } \\
\text { Cristóvão } \\
\text { do Sul }\end{array}$ & 50,72 \\
\hline Água Doce & 59,79 & $\begin{array}{c}\text { Caxambu } \\
\text { do Sul }\end{array}$ & 54,10 & Irati & 57,35 & Palhoça & 57,75 & $\begin{array}{c}\text { São } \\
\text { Domingos }\end{array}$ & 56,95 \\
\hline $\begin{array}{l}\text { Águas de } \\
\text { Chapecó }\end{array}$ & 58,17 & Celso Ramos & 66,52 & Irineópolis & 58,68 & Palma Sola & 57,56 & $\begin{array}{c}\text { São } \\
\text { Francisco } \\
\text { do Sul }\end{array}$ & 60,64 \\
\hline Águas Frias & 63,77 & Cerro Negro & 51,04 & Itá & 64,84 & Palmeira & 50,59 & $\begin{array}{c}\text { São João } \\
\text { Batista }\end{array}$ & 62,18 \\
\hline $\begin{array}{l}\text { Águas } \\
\text { Mornas }\end{array}$ & 60,96 & $\begin{array}{c}\text { Chapadão do } \\
\text { Lageado }\end{array}$ & 55,83 & Itaiópolis & 59,12 & Palmitos & 64,42 & $\begin{array}{l}\text { São João do } \\
\text { Itaperiú }\end{array}$ & 56,78 \\
\hline $\begin{array}{l}\text { Alfredo } \\
\text { Wagner }\end{array}$ & 55,52 & Chapecó & 63,92 & Itajaí & 62,93 & Papanduva & 59,92 & $\begin{array}{l}\text { São João do } \\
\text { Oeste }\end{array}$ & 69,58 \\
\hline $\begin{array}{l}\text { Alto Bela } \\
\text { Vista }\end{array}$ & 66,37 & Cocal do Sul & 69,87 & Itapema & 66,53 & Paraíso & 50,95 & $\begin{array}{c}\text { São João } \\
\text { do Sul }\end{array}$ & 62,16 \\
\hline Anchieta & 59,38 & Concórdia & 67,24 & Itapiranga & 70,15 & $\begin{array}{l}\text { Passo de } \\
\text { Torres }\end{array}$ & 57,73 & $\begin{array}{c}\text { São } \\
\text { Joaquim }\end{array}$ & 54,77 \\
\hline Angelina & 62,24 & $\begin{array}{l}\text { Cordilheira } \\
\text { Alta }\end{array}$ & 63,49 & Itapoá & 55,18 & Passos Maia & 51,63 & São José & 66,35 \\
\hline $\begin{array}{c}\text { Anita } \\
\text { Garibaldi }\end{array}$ & 58,85 & $\begin{array}{l}\text { Coronel } \\
\text { Freitas }\end{array}$ & 59,16 & Itupo & 64,83 & Paulo Lopes & 60,21 & $\begin{array}{l}\text { São José do } \\
\text { Cedro }\end{array}$ & 60,21 \\
\hline Anitápolis & 59,09 & $\begin{array}{l}\text { Coronel } \\
\text { Martins }\end{array}$ & 59,14 & Jaborá & 59,27 & $\begin{array}{c}\text { Pedras } \\
\text { Grandes }\end{array}$ & 60,76 & $\begin{array}{l}\text { São José do } \\
\text { Cerrito }\end{array}$ & 54,07 \\
\hline $\begin{array}{l}\text { Antônio } \\
\text { Carlos }\end{array}$ & 68,59 & Correia Pinto & 57,63 & $\begin{array}{l}\text { Jacinto } \\
\text { Machado }\end{array}$ & 62,73 & Penha & 59,14 & $\begin{array}{c}\text { São } \\
\text { Lourenço } \\
\text { do Oeste }\end{array}$ & 62,02 \\
\hline Apiúna & 59,43 & Corupá & 63,87 & Jaguaruna & 61,74 & Peritiba & 68,88 & São Ludgero & 68,96 \\
\hline Arabutã & 61,03 & Criciúma & 65,41 & Jaraguá do Sul & 72,31 & Petrolândia & 62,58 & $\begin{array}{c}\text { São } \\
\text { Martinho }\end{array}$ & 67,54 \\
\hline Araquari & 55,96 & Cunha Porã & 65,85 & Jardinópolis & 59,61 & Pinhalzinho & 65,16 & $\begin{array}{l}\text { São Miguel } \\
\text { da Boa Vista }\end{array}$ & 60,49 \\
\hline Araranguá & 62,88 & Cunhataí & 59,75 & Joaçaba & 68,96 & $\begin{array}{l}\text { Pinheiro } \\
\text { Preto }\end{array}$ & 66,58 & $\begin{array}{l}\text { São Miguel } \\
\text { do Oeste }\end{array}$ & 67,76 \\
\hline Armazém & 64,44 & Curitibanos & 56,93 & Joinville & 68,17 & Piratuba & 64,66 & $\begin{array}{c}\text { São Pedro } \\
\text { de Alcântara }\end{array}$ & 56,46 \\
\hline Arroio Trinta & 74,37 & Descanso & 61,19 & José Boiteux & 60,60 & $\begin{array}{l}\text { Planalto } \\
\text { Alegre }\end{array}$ & 60,26 & Saudades & 67,57 \\
\hline Arvoredo & 57,70 & $\begin{array}{c}\text { Dionísio } \\
\text { Cerqueira }\end{array}$ & 52,99 & Jupiá & 60,30 & Pomerode & 68,20 & Schroeder & 65,00 \\
\hline Ascurra & 63,23 & Dona Emma & 65,49 & Lacerdópolis & 67,43 & Ponte Alta & 55,45 & Seara & 63,30 \\
\hline Atalanta & 64,35 & $\begin{array}{c}\text { Doutor } \\
\text { Pedrinho }\end{array}$ & 62,65 & Lages & 60,98 & $\begin{array}{l}\text { Ponte Alta } \\
\text { do Norte }\end{array}$ & 62,48 & Serra Alta & 66,37 \\
\hline Aurora & 65,04 & Entre Rios & 48,04 & Laguna & 61,92 & $\begin{array}{l}\text { Ponte } \\
\text { Serrada }\end{array}$ & 54,56 & Siderópolis & 64,01 \\
\hline $\begin{array}{c}\text { Balneário } \\
\text { Arroio do } \\
\text { Silva }\end{array}$ & 56,31 & Ermo & 65,50 & $\begin{array}{l}\text { Lajeado } \\
\text { Grande }\end{array}$ & 59,60 & Porto Belo & 60,40 & Sombrio & 59,57 \\
\hline $\begin{array}{c}\text { Balneário } \\
\text { Barra do Sul }\end{array}$ & 61,08 & Erval Velho & 67,38 & Laurentino & 66,57 & Porto União & 63,27 & Sul Brasil & 54,95 \\
\hline $\begin{array}{l}\text { Balneário } \\
\text { Camboriú }\end{array}$ & 68,51 & $\begin{array}{l}\text { Faxinal dos } \\
\text { Guedes }\end{array}$ & 66,31 & Lauro Müller & 61,01 & $\begin{array}{c}\text { Pouso } \\
\text { Redondo }\end{array}$ & 62,47 & Taió & 63,16 \\
\hline $\begin{array}{c}\text { Balneário } \\
\text { Gaivota }\end{array}$ & 60,32 & $\begin{array}{l}\text { Flor do } \\
\text { Sertão }\end{array}$ & 54,78 & Lebon Régis & 49,22 & $\begin{array}{c}\text { Praia } \\
\text { Grande }\end{array}$ & 64,22 & Tangará & 61,55 \\
\hline $\begin{array}{l}\text { Balneário } \\
\text { Piçarras }\end{array}$ & 56,03 & Florianópolis & 69,35 & Leoberto Leal & 51,66 & $\begin{array}{c}\text { Presidente } \\
\text { Castello } \\
\text { Branco }\end{array}$ & 60,50 & Tigrinhos & 56,55 \\
\hline
\end{tabular}


Tabela A3. SPI dos munícipios de Santa Catarina

\begin{tabular}{|c|c|c|c|c|c|c|c|c|c|}
\hline Município & SPI & Município & SPI & Município & SPI & Município & SPI & Município & SPI \\
\hline Bandeirante & 49,63 & $\begin{array}{c}\text { Formosa do } \\
\text { Sul }\end{array}$ & 59,40 & Lindóia do Sul & 62,54 & $\begin{array}{l}\text { Presidente } \\
\text { Getúlio }\end{array}$ & 62,75 & Tijucas & 64,11 \\
\hline Barra Bonita & 51,66 & Forquilhinha & 60,34 & Lontras & 63,45 & $\begin{array}{l}\text { Presidente } \\
\text { Nereu }\end{array}$ & 62,50 & $\begin{array}{c}\text { Timbé do } \\
\text { Sul }\end{array}$ & 57,40 \\
\hline Barra Velha & 57,89 & Fraiburgo & 62,00 & Luiz Alves & 59,07 & Princesa & 56,31 & Timbó & 70,79 \\
\hline $\begin{array}{l}\text { Bela Vista } \\
\text { do Toldo }\end{array}$ & 53,01 & Frei Rogério & 65,11 & Luzerna & 72,71 & Quilombo & 62,40 & $\begin{array}{l}\text { Timbó } \\
\text { Grande }\end{array}$ & 47,80 \\
\hline Belmonte & 54,37 & Galvão & 55,21 & Macieira & 58,54 & $\begin{array}{c}\text { Rancho } \\
\text { Queimado }\end{array}$ & 65,53 & Três Barras & 53,52 \\
\hline $\begin{array}{c}\text { Benedito } \\
\text { Novo }\end{array}$ & 62,28 & Garopaba & 64,92 & Mafra & 61,87 & $\begin{array}{c}\text { Rio das } \\
\text { Antas }\end{array}$ & 61,72 & Treviso & 63,71 \\
\hline Biguaçu & 57,48 & Garuva & 58,60 & Major Gercino & 55,60 & $\begin{array}{l}\text { Rio do } \\
\text { Campo }\end{array}$ & 64,44 & $\begin{array}{c}\text { Treze de } \\
\text { Maio }\end{array}$ & 62,71 \\
\hline Blumenau & 68,58 & Gaspar & 63,10 & Major Vieira & 54,06 & $\begin{array}{l}\text { Rio do } \\
\text { Oeste }\end{array}$ & 64,10 & Treze Tílias & 67,30 \\
\hline $\begin{array}{c}\text { Bocaina do } \\
\text { Sul }\end{array}$ & 54,42 & $\begin{array}{l}\text { Governador } \\
\text { Celso Ramos }\end{array}$ & 64,14 & Maracajá & 61,23 & Rio do Sul & 66,67 & $\begin{array}{c}\text { Trombudo } \\
\text { Central }\end{array}$ & 65,94 \\
\hline $\begin{array}{c}\text { Bom Jardim } \\
\text { da Serra }\end{array}$ & 55,91 & Grão Pará & 63,37 & Maravilha & 66,25 & $\begin{array}{l}\text { Rio dos } \\
\text { Cedros }\end{array}$ & 62,89 & Tubarão & 68,57 \\
\hline Bom Jesus & 61,46 & Gravatal & 64,35 & Marema & 62,61 & Rio Fortuna & 67,15 & Tunápolis & 67,07 \\
\hline $\begin{array}{l}\text { Bom Jesus } \\
\text { do Oeste }\end{array}$ & 61,73 & Guabiruba & 63,36 & Massaranduba & 67,34 & $\begin{array}{c}\text { Rio } \\
\text { Negrinho }\end{array}$ & 61,68 & Turvo & 65,33 \\
\hline Bom Retiro & 56,97 & Guaraciaba & 62,46 & Matos Costa & 51,86 & Rio Rufino & 59,76 & $\begin{array}{c}\text { União do } \\
\text { Oeste }\end{array}$ & 59,83 \\
\hline Bombinhas & 63,67 & Guaramirim & 62,17 & Meleiro & 65,35 & Riqueza & 60,58 & Urubici & 56,92 \\
\hline Botuverá & 63,71 & $\begin{array}{c}\text { Guarujá do } \\
\text { Sul }\end{array}$ & 62,79 & Mirim Doce & 63,06 & Rodeio & 65,24 & Urupema & 60,54 \\
\hline $\begin{array}{c}\text { Braço do } \\
\text { Norte }\end{array}$ & 66,40 & Guatambu & 49,84 & Modelo & 62,58 & Romelândia & 57,77 & Urussanga & 67,74 \\
\hline $\begin{array}{l}\text { Braço do } \\
\text { Trombudo }\end{array}$ & 65,58 & $\begin{array}{l}\text { Herval } \\
\text { d'Oeste }\end{array}$ & 58,67 & Mondaí & 60,87 & Salete & 63,98 & Vargeão & 63,93 \\
\hline Brunópolis & 55,30 & Ibiam & 63,66 & Monte Carlo & 52,88 & Saltinho & 54,04 & Vargem & 58,86 \\
\hline Brusque & 65,87 & Ibicaré & 64,74 & Monte Castelo & 53,41 & Salto Veloso & 67,20 & $\begin{array}{c}\text { Vargem } \\
\text { Bonita }\end{array}$ & 59,09 \\
\hline Caçador & 58,71 & Ibirama & 65,08 & $\begin{array}{l}\text { Morro da } \\
\text { Fumaça }\end{array}$ & 63,95 & Sangão & 55,25 & Vidal Ramos & 62,58 \\
\hline Caibi & 62,73 & Içara & 62,69 & Morro Grande & 61,83 & $\begin{array}{l}\text { Santa } \\
\text { Cecília }\end{array}$ & 52,10 & Videira & 64,69 \\
\hline Calmon & 39,05 & Ilhota & 58,52 & Navegantes & 57,93 & $\begin{array}{c}\text { Santa } \\
\text { Helena }\end{array}$ & 62,90 & $\begin{array}{c}\text { Vitor } \\
\text { Meireles }\end{array}$ & 59,66 \\
\hline Camboriú & 55,91 & Imaruí & 57,17 & Nova Erechim & 61,79 & $\begin{array}{l}\text { Santa Rosa } \\
\text { de Lima }\end{array}$ & 66,37 & Witmarsum & 63,95 \\
\hline $\begin{array}{l}\text { Campo } \\
\text { Alegre }\end{array}$ & 59,38 & Imbituba & 65,37 & $\begin{array}{c}\text { Nova } \\
\text { Itaberaba }\end{array}$ & 56,43 & $\begin{array}{c}\text { Santa Rosa } \\
\text { do Sul }\end{array}$ & 63,07 & Xanxerê & 59,42 \\
\hline $\begin{array}{c}\text { Campo Belo } \\
\text { do Sul }\end{array}$ & 55,17 & Imbuia & 63,98 & Nova Trento & 64,67 & $\begin{array}{c}\text { Santa } \\
\text { Terezinha }\end{array}$ & 59,42 & Xavantina & 59,84 \\
\hline Campo Erê & 52,75 & Indaial & 65,23 & Nova Veneza & 67,11 & $\begin{array}{c}\text { Santa } \\
\text { Terezinha } \\
\text { do } \\
\text { Progresso }\end{array}$ & 53,99 & Xaxim & 61,56 \\
\hline $\begin{array}{c}\text { Campos } \\
\text { Novos }\end{array}$ & 61,70 & lomerê & 70,88 & $\begin{array}{c}\text { Novo } \\
\text { Horizonte }\end{array}$ & 56,43 & $\begin{array}{c}\text { Santiago } \\
\text { do Sul }\end{array}$ & 60,01 & Zortéa & 66,28 \\
\hline Canelinha & 59,85 & Ipira & 63,07 & Orleans & 64,76 & $\begin{array}{c}\text { Santo } \\
\text { Amaro da } \\
\text { Imperatriz }\end{array}$ & 62,64 & & \\
\hline Canoinhas & 63,01 & $\begin{array}{l}\text { Iporã do } \\
\text { Oeste }\end{array}$ & 68,09 & Otacílio Costa & 64,04 & $\begin{array}{l}\text { São Bento } \\
\text { do Sul }\end{array}$ & 66,55 & & \\
\hline
\end{tabular}

